\title{
IMPLEMENTASI PROGRAM KESEJAHTERAAN KELUARGA HARAPAN DI KECAMATAN BONE-BONE KABUPATEN LUWU UTARA
}

\author{
Implementation of the Hope Family Welfare Program in Bone-Bone District, North Luwu Regency \\ Hasmini $^{1}$, Andi Rasjid Pananrangi ${ }^{2}$, Syamsudin Maldun ${ }^{2}$ \\ ${ }^{1}$ Pemerintah Kecematan Bone-Bone, Kabupaten Luwu Utara \\ ${ }^{2}$ Program Studi Ilmu Administrasi Negara, Program Pascasarjana, Universitas Bosowa \\ Email: hasmini@gmail.com \\ Diterima: 25 September 2021 \\ Dipublikasikan: 24 Desember 2021
}

\begin{abstract}
ABSTRAK
Penelitian ini bertujuan 1) Untuk mengetahui dan menganalisis upaya pemerintah kecamatan Bone-Bone kabupaten Luwu Utara dalam meningkatkan kesejahteraan masyarakat. 2) Untuk mengetahui dan menganalisis faktor apa yang menghambat upaya peningkatan kesejahteraan masyarakat di kecamatan Bone-Bone kabupaten Luwu Utara. Penelitian ini menggunakan metode kualitatif. Pengumpulan data dilakukan dengan teknik: observasi, wawancara, penelusuran data online dan dokumentasi. Jenis dan sumber data dalam penelitian ini diperoleh dari data primer dan data sekunder. Hasil penelitian menunjukan bahwa upaya pemerintah kecamatan Bone-Bone Kabupaten Luwu Utara dalam meningkatkan kesejahteraan masyarakat sudah cukup berjalan dengan baik akan tetapi masih ada beberapa hal yang perlu diperbaiki dan di tata lebih baik lagi seperti para pendamping PKH tidak melibatkan masyarakat umum dalam sosialisasi PKH sehingga banyak masyarakat yang seharusnya mendapatkan bantuan PKH namun tidak menerima bantuan. Kurangnya pengetahuan calon PKH tentang prosedur PKH mengakibatkan terjadinya masalah seperti ketika para calon PKH telah terdaftar menjadi penerima PKH namun saat validasi ternyata tidak susuai dengan syarat yang telah ditetapkan, seperti harus adanya komponen pendidikan, kesehatan dan kesejahteraan sosial, sehingga terjadilah kecemburuan sosial antara masyarakat tersebut.
\end{abstract}

Kata Kunci: Program Keluarga Harapan, Kemiskinan, Luwu Utara

\section{ABSTRACT}

This study aims 1) To determine and analyze the efforts of the Bone-Bone sub-district government, North Luwu district in improving the welfare of the community. 2) To find out and analyze what factors hinder efforts to improve community welfare in Bone-Bone sub-district, North Luwu district. This study uses a qualitative method. Data was collected using the following techniques: observation, interview, online data search and documentation. The types and sources of data in this study were obtained from primary data and secondary data. The results showed that the efforts of the Bone-Bone sub-district government of North Luwu Regency in improving the welfare of the community had gone well enough but there were still some things that needed to be improved and better managed, such as PKH facilitators not involving the general public in PKH socialization so that many people who should have received PKH assistance but did not receive assistance. The lack of knowledge of PKH candidates about PKH procedures results in problems such as when PKH candidates have been registered as PKH recipients but during validation it turns out that they do not comply with the conditions that have been set, such as the existence of components of education, health and social welfare, so that social jealousy occurs between the community.

Keywords: Family Hope Program, Poverty, Luwu Utara

This work is licensed under Creative Commons Attribution License 4.0 CC-BY International license

\section{PENDAHULUAN}

Indonesia memiliki masalah kemiskinan masih menjadi sorotan utama terkait dengan usaha-usaha pemerintah dalam meningkatkan kesejahteraan sosial masyarakat. Kemiskinan dan pengangguran bagaikan setumpuk gunung es yang harus segera dipecahkan. Tujuan utama dari peningkatan kesejahteraan masyarakat adalah penanggulangan kemiskinan. Meskipun peningkatan kesejahteraan masyarakat dibuat untuk kebutuhan publik yang sangat luas, namun target utama dalam upaya ini adalah masyarakat yang memerlukan, yaitu orang miskin, anak-anak dan wanita korban kekerasan, anak jalanan, pekerja anak, dan orang dengan kemampuan berbeda (difabel).

Permasalahan kebijakan atau sering disebut sebagai implementation gap adalah suatu keadaan dimana dalam proses perumusan kebijakan dimana kemungkinan perbedaan antara apa yang direncanakan oleh pembuat kebijakan dengan apa yang terjadi sebagai hasil atau prestasi dari pelaksanaan kebijakan tersebut. Hal ini salah satunya dikarenakan dalam proses implementasi kebijakan seringkali dipengaruhi oleh banyak kepentingan dan harapan terutama pengaruh persepsi dari lingkungan dimana kebijakan itu dilaksanakan. 
Menurut Elis (1984) sebagaimana yang dikutip oleh Edi Suharto (2017) menyatakan bahwa dimensi kemiskinan menyangkut tiga aspek yaitu aspek ekonomi, politik, dan sosial-psikologis. Secara ekonomi kemiskinan dapat difinisikan sebagai kekurangan sumber daya yang dapat digunakan untuk memenuhi kebutuhan hidup yang meningkatkan kesejahteraan sekelompok orang. Secara politik, kemiskinan dapat dilihat dari tingkat akses terhadap kekuasaan (Power). Kekuasaan dalam pengertian ini mencakup tatanan sistem politik yang dapat menentukan kemampuan sekelompok orang dalam menjangkau sumber daya. Sedangkan secara sosialpsikologis menunjukan pada kekurangan jaringan dan struktur sosial yang mendukung dalam mendapatkan kesempatan-kesempatan peningkatan produktivitas. Oleh karena itu, dengan adanya kebijakan dari pemerintah untuk menangani suatu persoalan kemiskinan tentunya masyarakat yang dikategorikan miskin akan menginginkan yang namanya kesejahteraan hidup agar tidak ada kesenjangan kehidupan antara orang miskin dan orang kaya.

Sebagaimana yang dituangkan oleh peraturan Menteri Sosial Republik Indonesia No. 6 (Pasal 1 point 4) tahun 2016 tentang Tanggung Jawab Sosial Badan Usaha Dalam Penyelenggaraan Sosial bahwasanya kesejahteraan sosial adalah:

"Kondisi terpenuhinya kebutuhan material, spiritual, dan sosial warga negara agar dapat hidup layak dan mampu mengembangkan diri, sehingga dapat melaksanakan fungsi sosialnya".

Artinya adalah dalam hal ini pemerintah berkewajiban berkontribusi penuh untuk memenuhi kebutuhan masyarakatnya agar mendapatkan hidup layak dan dapat menigkatkan taraf kesejahteraan serta kualitas dan kelangsungan hidup.

Adapun tujuan kesejahteraan sosial menurut UU No.6 (Pasal 2 point 2) tahun 2016 bahwa penyelenggaraan kesejahteraan sosial bertujuan: a) Tertanganinya berbagai permasalahan sosial. b)Terentaskannya penyandang masalah kesejahteraan sosial. c.) Terwujudnya peningkatan Kesejahteraan Sosial masyarakat; dan Berdasarkan data BPS pusat pada september 2017: "Jumlah penduduk miskin di Indonesia mencapai 26,58 juta orang $(10,12 \%)$, berkurang sebesar 1,19 juta orang dibandingkan dengan kondisi Maret 2017 yang sebesar 27,77 juta orang (10,64\%)". (BPS, 2018).

Menurut data Badan Pusat Statistik (BPS) tingkat kemiskinan di kabupaten Luwu Utara pada tahun 2018 berada pada angka sebesar 11,25 persen. Hal ini menunjukkan bahwa tingkat persentase penduduk miskin di kabupaten Luwu Utara masih tinggi. Penurunan angka kemiskinan kabupaten Luwu Utara hanya turun 0,48 persen dibandingkan tahun sebelumnya yaitu pada tahun 2019 yaitu berada pada angka 10,77 persen, oleh karena itu pemerintah kabupaten Luwu Utara melalui dinas terkait melakukan evaluasi menyeluruh terhadap program pengentasan kemiskinan.
Untuk mengurangi permasalahan kemiskinan, pemerintah memiliki berbagai program penanggulangan kemiskinan mulai dari penanggulangan berbasis bantuan sosial, pemberdayaan masyarakat serta pemberdayaan usaha kecil. Salah satu program yang berbasis bantuan sosial dari pemerintah adalah Program Keluarga Harapan (PKH). Sebagaiman telah diatur dalam Undang-undang No. 10 Tahun 2017 bahwa Program Keluarga Harapan (PKH) adalah program pemberian bantuan sosial bersyarat kepada keluarga miskin dan rentan yang terdaftar dalam data terpadu penanganan fakir miskin, diolah oleh Pusat Data dan Informasi Kesejahteraan Sosial dan ditetapkan sebagai keluarga penerima manfaat PKH.

Kabupaten Luwu Utara merupakan salah satu Kabupaten yang melaksanakan Program Keluarga Harapan. Kabuaten Luwu Utara berada di Provinsi Sulawesi Selatan. Salah satu kecamatan yang ada di Kabupaten Luwu Utara yang melaksanakan Program Keluarga Harapan (PKH) yaitu Kecamatan Bone-Bone yang terdiri dari 11 Desa.

Kecamatan Bone-Bone merupakan salah satu Kecamatan yang mempunyai jumlah keluarga miskin yang cukup banyak. Program Keluarga Harapan di Kecamatan Bone-Bone mulai dilaksanakan pada tahun 2013. Pelaksanaan PKH di Kecamatan Bone-Bone sudah berjalan 5 tahun. Dengan adanya program PKH di Kecamatan Bone-Bone diharapkan bisa mengurangi kemiskinan dan meningkatkan kualitas sumberdaya manusia yaitu Pendidikan, Kesehatan, dan Kesejahteraan Sosial terhadap kelompok masyarakat miskin. Program Keluarga Harapan yang dilaksanakan di Kecamatan Bone-Bone dalam pelaksanaannya sudah cukup baik. Namun dalam pra penelitian, implementasi dari program ini belum terlaksana secara optimal. Yang pada dasarnya program ini dikhususkan kepada masyarakat kurang mampu atau masyarakat miskin. Tetapi yang terjadi, masyarakat mempersoalkan adanya peserta atau calon peserta $\mathrm{PKH}$ yang dinilai tidak termasuk keluarga miskin. (survei pada tanggal 17 Oktober 2018)

Dari hasil observasi awal yang dilakukan oleh peneliti di kecamatan Bone-Bone kabupaten Luwu Utara pada tanggal 7 September 2020 ditemukan berbagai strategi yang dilakukan oleh pemerintah terkait dengan peningkatan kesejahteraan masyarakat. Strategi penanggulangan kemiskinan yang telah diterapkan pemerintah kabupaten Luwu Utara adalah peningkatan produktivitas/kapasitas penduduk miskin melalui berbagai program pemberdayaan seperti, peningkatan daya beli masyarakat miskin melalui pengendalian inflasi, kenaikan subsidi dan bantuan sosial, peningkatan akses terhadap akses pelayanan dasar seperti pendidikan, kesehatan, air bersih dan infrastruktur lainnya, pemberdayaan Usaha Mikro Kecil dan Menengah (UMKM), pengendalian jumlah penduduk melalui program keluarga berencana (KB) dan program-program terkait lainnya. 


\section{METODE}

Penelitian ini menggunakan metode kualitatif karena dilakukan pada kondisi yang alamiah. Teknik pengumpulan data dilakukan dengan metode observasi, wawancara, studi kepustakaan (Library Research), dan penelusuran data online. Teknik analisis data pada penelitian ini dilakukan secara cermat dimana data diseleksi mengggunakan teknik analisis data deskriptif yaitu data-data yang telah dihimpun dan dikumpulkan baik primer maupun sekunder, kemudian diambil kesimpulan sebagai jawaban masalah yang diteliti. Pengolahan data diakukan melalui reduksi data, penyajian data dan penarikan kesimpulan dan verifikasi data. Sementara itu kredibilitas data dalam penelitian ini dilakukan melalui perpanjangan pengamatan, meningkatkan ketekunan, triangulasi data, analisis kasus negatif, menggunakan bahan referensi

\section{HASIL DAN PEMBAHASAN}

Setelah melakukan penelitian dilapangan (observasi dan wawancara), maka didapatkan dari hasil wawancara dengan memberikan pertanyaan kepada informan yang terkait mengenai tujuan penelitian yaitu mengetahui dan menganalisis upaya pemerintah Kecamatan Bone-Bone Kabupaten Luwu Utara dalam meningkatkan kesejahteraan masyarakat dan mengetahui dan menganalisis faktor apa yang menghambat upaya peningkatan kesejahteraan masyarakat di Kecamatan Bone-Bone kabupaten Luwu Utara. Adapun tujuan penelitian dalam penelitian ini adalah sebagai berikut:

Upaya pemerintah Kecamatan Bone-Bone Kabupaten Luwu Utara dalam meningkatkan kesejahteraan masyarakat

Upaya pemerintah kecamatan Bone-Bone Kabupaten Luwu Utara dalam meningkatkan kesejahteraan masyarakat mengacu pada Pedoman Umum Pelaksanaan Program Keluarga Harapan 2019, terdapat indikator-indikator untuk melakukan pengukuran kebijakan Program Keluarga Harapan agar implementasi kebijakan pemerintah dalam meningkatkan kesejahteraan masyarakat menjadi efektif dan maksimal, antara lain:

a. Penetapan Program Keluarga Harapan (PKH)

Penetapan Program Keluarga Harapan (PKH) sesuai dengan pedoman umum Program Keluarga Harapan (PKH) yang penulis jadikan sebagai indikator pertama dalam melakukan penelitian. Di dalam penetapan Program Keluarga Harapan (PKH) ini terdapat sub indikator yaitu: Pendataan PKH dan Verifikasi Data PKH.

1) Pendataan Program Keluarga Harapan $\mathrm{PKH}$

Dalam Pedoman Umum PKH Tahun 2019 bahwa sosialisasi dan komunikasi PKH dirancang untuk terjadinya proses komunikasi, aliran informasi, dan pembelajaran pada berbagai pelaksana di pusat dan daerah, kalangan media, LSM, akademisi dan masyarakat, termasuk Peserta PKH, terutama di daerah PKH. Tersosialisasikannya PKH kepada semua pihak, baik yang terkait langsung maupun tidak langsung, merupakan kunci kesuksesan PKH. Untuk itu disusun strategi komunikasi dan sosialisasi PKH yang komprehensif sebelum dilakukan pendataan PKH. Strategi komunikasi dan sosialisasi ini tidak hanya memfokuskan pada aspek implementasi dan keberhasilan pelaksanaan program $\mathrm{PKH}$, tetapi juga aspek pengembangan kebijakan, khususnya dalam pembangunan dukungan dan komitmen untuk melembagakan PKH dalam bentuk Sistem Jaminan Sosial.

Pemilihan Peserta PKH dilakukan dengan melakukan survey di lokasi program untuk mendapat data rumah tangga miskin. Data yang telah disusun tersebut kemudian disaring kembali berdasar syarat kepesertaan PKH. Hasil saringan tersebut kemudian menetapkan PKH tersebut sebagai calon peserta $\mathrm{PKH}$ melalui sistem ranking.

Berdasarkan hasil penelitian bahwa pendataan penerima Program PKH di dapatkannya dari Pemerintah Pusat. Dirinya belum meyakini apakah data yang digunakan berdasarkan data BDT atau data yang lain. Dalam pendataan tersebut dilakukan proses pemilihan peserta program PKH yang layak menerima sesuai kriteria yang ditentukan, Proses pendataan penerima program $\mathrm{PKH}$ yang dialami oleh peserta penerima Program PKH diakuinya tidak tahu menahu. Mereka mengetahui bahwa dirinya menjadi peserta Program PKH dari pemberitahuan surat yang diterimanya dari Aparatur Desa.

Sedangkan sosialisasi tentang Program Keluarga Harapan di Desa Pongko kepada peserta PKH ada dilakukan, pada umumnya PKH mengetahui dan cukup mengerti apa itu PKH. Dari proses pendataan dalam menentukan peserta penerima Program PKH di Desa Pongko sudah dilakukan dengan prosedur dan ketentuan Program PKH, akan tetapi walaupun sosialisasi PKH ada dilakukan, pada umumnya masyarakat tidak paham mengenai proses pendataan penerima $\mathrm{PKH}$, masih banyak masyarakat yang semestinya masuk dalam kriteria sebagai penerima Program PKH, tetapi belum mendapatkan. Jika melihat kondisi dari fenomena tersebut, sosialisai mengenai PKH juga perlu melibatkan masyarakat dan tokoh-tokoh masyarakat agar seluruh masyarakat paham apa itu PKH dan pemutakhiran data perlu dilakukan dengan benar, sehingga peserta yang harus mendapatkan sesuai dengan target tujuan program $\mathrm{PKH}$.

2) Verifikasi Data Program Keluarga Harapan (PKH)

Didalam suatu rumah tangga dikategorikan sebagai mendapat Program Keluarga Harapan (PKH) jika rumah tangga tersebut memenuhi indikator kemiskinan yang dikembangkan dari hasil model estimasi menggunakan faktor-faktor yang secara statistik memiliki korelasi dengan kemiskinan multidimensi, seperti antara lain kondisi demografi dan sosiol ekonomi. Indikatorindikator ini lebih lanjut dikembangkan ke dalam kuesioner yang digunakan untuk memverifikasi status kemiskinan rumah tangga. 
Setelah mendapatkan data nama-nama dari pusat yang akan menjadi PKH selanjutnya pendamping desa turun kelapangan untuk memastikan layak atau tidak layaknya PKH tersebut.

Verifikasi data program keluarga harapan $(\mathrm{PKH})$ di Kecamatan Bone-Bone melakukan dengan cukup baik dan sesuai prosedur, tapi proses verifikasinya hanya diketahui oleh petugas-petugas PKH. Seharusnya petugaspetugas PKH memahami dan menjelaskan kepada masyarakat agar masyarakat memahami proses-proses verifikasi data dan mengerti sehingga terciptanya transparansi dalam proses pendataan calon $\mathrm{PKH}$.

b. Hak Penerima Program Keluarga Harapan

Peraturan Menteri Sosial Republik Indonesia Nomor 1 Tahun 2018 Tentang Program Keluarga Harapan (PKH) mendapatkan haknya sebagai peserta $\mathrm{PKH}$, yaitu mendapatkan pelayanan uang tunai, pelayanan kesehatan dan pelayanan pendidikan.

1) Pelayanan Uang Tunai

Salah satu tugas pendamping PKH ialah memberikan pelayanan uang tunai bagi peserta PKH, pelayanan yang diberikan berupa pemberian informasi kepada peserta PKH tentang uang tunai masuk ke masingmasing rekening $\mathrm{PKH}$.

Berdasarkan hasil penelitian bahwa pendamping disini hanya memberikan info ke ketua peserta PKH bahwa dana sudah cair, tidak ada pendampingan yang dilakukan oleh pendamping atau melihat para PKH dalam proses pencairan dana $\mathrm{PKH}$, sehingga ketika terjadi masalah seperti saldo belum masuk, tidak dapat langsung ditangani oleh pendamping, Berdasarkan Petunjuk Teknis Penyaluran Bantuan PKH 2019 bahwasanya Pendamping secara aktif memantau pencairan bantuan sosial dan melaporkan ke Koordinator Kabupaten/kota jumlah yang telah menerima Bansos PKH di tabungan, untuk itu akan lebih baik jikalau pendamping ini bisa langsung turun ketika PKH mengambil uangnya.

2) Pelayanan Kesehatan

Selain pelayanan uang tunai pendamping PKH juga memberikan pelayanan kesehatan kepada peserta PKH, diantaranya yaitu pelayanan untuk balita, Ibu hamil dan lansia. Dalam Pedoman Umum Pelaksanaan PKH 2019 di jelaskan bahwasanya Rendahnya penghasilan menyebabkan keluarga miskin tidak mampu memenuhi kebutuhan kesehatan dan pendidikan, bahkan untuk tingkat minimal sekalipun.

Berdasarkan hasil penelitian bahwa program kesehatan yang dilakukan oleh pendamping PKH telah dilakukan dan tersosialisi dengan baik kepada PKH di Kecamatan Bone-Bone. Semoga dengan aktifnya peserta PKH ini dalam melakukan pemerikasaan kesehatannya dapat menigkatkan kesehatan bagi ibu dan bayi dan ini akan berdampak baik untuk masa yang akan datang, karena sehat sangat mahal.

3) Pelayanan Pendidikan

Tiada cara yang paling cepat untuk mengubah diri, keluarga dan masyarakat kecuali melalui pendidikan. Masyarakat desa juga sudah memiliki kesadaran yang sama dalam meningkatkan kualitas sumber manusia melalui peningkatan ilmu dan kemahiran yaitu pendidikan. Namun permsalahan umum berlaku pada masyarakat miskin desa adalah tiada kemampuan untuk membiayai sekolah/kuliah anak akibat beban ekonomi yang cukup berat. Oleh itu, sangat wajar jika masyarakat miskin desa memerlukan bantuan pendidikan agar anakanak mereka dapat melanjutkan pendidikan setinggi mungkin.

Berdasarkan hasil penelitian dapat di ketahui untuk hak penerima program keluarga harapan telah di terima oleh masyarakat PKH sudah baik sesuai dengan prosedur yang telah di tetapkan. Karena masyarakat yang mendapatkan PKH dapat meringankan dalam pembayaran uang sekolah bagi yang sekolah di swasta, karna negeri tidak bayar, berupa adanya pemberian jatah waktu pembayaran yang sedikit lama dari pada siswa lainnya dikarenakan mendapatkan program $\mathrm{PKH}$, begitu juga yang telah diungkapkan oleh pendamping PKH bahwa anak yang mendapatkan bantuan PKH diberikan keringanan dalam pembayar uang sekolah berupa perpanjangan waktu sehingga ketika uang tunai PKH telah keluar bisa langsung di bayar kan ke sekolah anak tersebut.

\section{c. Kewajiban PKH}

Sesuai dengan pedoman umum Program Keluarga Harapan $(\mathrm{PKH})$, di dalam kewajiban masyarakat yang mendapatkan program keluarga harapan $(\mathrm{PKH})$ terdapat sub indikator yaitu: Pemeriksaan syarat $\mathrm{PKH}$, kehadiran sekolah bagi anak dan kehadiran pemeriksaan kesehatan.

1) Pemeriksaan Syarat Program Keluarga Harapan (PKH)

Didalam Permensos RI Nomor 1 Tahun 2018 disebutkan bahwa kewajiban masyarakat yang mendapatkan program keluarga harapan PKH berkewajiban untuk: a. Memeriksakan kesehatan pada fasilitas pelayanan kesehatan sesuai dengan protokol kesehatan bagi ibu hamil/menyusui dan anak berusia 0 (nol) sampai dengan 6 (enam) tahun; b. Mengikuti kegiatan belajar dengan tingkat kehadiran paling sedikit 85\% (delapan puluh lima persen) dari hari belajar efektif bagi anak usia sekolah wajib belajar 12 (dua belas) tahun; c. Mengikuti kegiatan di bidang kesejahteraan sosial sesuai dengan kebutuhan bagi keluarga yang memiliki komponen lanjut usia mulai dari 60 (enam puluh) tahun dan/atau penyandang disabilitas berat.

Dari hasil penelitian bahwa pemeriksaan syarat untuk PKH di Kecamatan Bone-Bone berjalan dengan baik dan sesuai dengan prosedur-prosedur yang telah ditetapkan, bahwasanya masyarakat PKH diwajibkan memeriksakan kesehatan ke layanan kesehatan yang telah di tetapkan khusus ibu hamil, balita dan lansia. Untuk anak diwajibkan mengikuti proses belajar dengan tingkat kehadiran 85\% apabila masyarakat PKH tidak melaksanakan kewajibannya untuk pertama akan di berikan teguran atau surat peringatan kalau sudah tiga kali berturut-turut maka akan dikeluarkan dari kepesertaan PKH. 
2) Kehadiran Sekolah Bagi Anak

Program Keluarga Harapan terdapat komponenkomponen, salah satunya yaitu Komponen Pendidikan meliputi: Anak Sekolah Dasar/Madrasah Ibtidaiyah atau sederajat, anak Sekolah Menengah Pertama/Madrasah Tsanawiyah atau sederajat, anak Sekolah Menengah Atas/Madrasah Aliyah atau sederajat, anak usia 6 (enam) sampai dengan 21 (dua puluh satu) tahun yang belum menyelesaikan wajib belajar 12 (dua belas) tahun. Syaratnya yaitu harus mengikuti kegiatan belajar dengan tingkat kehadiran paling sedikit $85 \%$ (delapan puluh lima persen) dari hari belajar efektif bagi anak usia sekolah wajib belajar 12 (dua belas) tahun.

Dari hasil penelitian bahwa untuk memastikan setiap peserta PKH menjalankan komitmennya sebagai peserta PKH maka pendamping PKH melakukan verifikasi, jikalau Peserta PKH tidak menjaga komitmennya maka akan di kenakan peringatan bahkan bisa di keluarkan dari kepesertaan PKH, atau yang menerima bantuan PKH komponen pendidikan harus memenuhi persyaratan kehadiran anak yang sekolah tersebut minimal $85 \%$. Pendamping akan melakukan pemutakhiran data dalam tiga bulan sekali dan yang tidak memenuhi persyaratan, maka bantuan PKH nya akan di cabut dan di hilangkan. Dari hasil wawancara di atas dapat disimpulkan bahwa pemeriksaan syarat bagi PKH di Kecamatan Bone-Bone pada komponen Pendidikan yaitu kehadiran pada anak berjalan dengan baik dan sesuai dengan ketentuan yang berlaku.

3) Kehadiran Pemeriksaan Kesehatan

Dalam kewajiban program keluarga harapan $(\mathrm{PKH})$ terdapat kehadiran pemeriksaan kesehatan. Dalam Panduan Umum Pelaksanaan PKH 2019 dinyatakan bahwa salah satu kewajiban dari penerima bantuan PKH adalah Memeriksakan kesehatan pada fasilitas pelayanan kesehatan sesuai dengan protokol kesehatan bagi ibu hamil/menyusui dan anak berusia 0 (nol) sampai dengan 6 (enam) tahun.

Dari hasil penelitian menunjukan bahwa terdapat kehadiran pemeriksaan kesehatan di lakukan untuk ibu hamil, mempunyai anak balita dan anak berusia nol sampai enam tahun. Sedangkan dalam melakukan kewajiban PKH dan pemeriksaan kewajiban yang di lakukan oleh pendamping PKH pada komponen kesehatan di Desa Sukaraya berjalan dengan baik dan sesuai dengan prosedur yang berlaku.

d. Pengawasan Program Keluarga Harapan (PKH)

1) Memastikan bantuan tepat sasaran

Sasaran PKH adalah keluarga miskin dan rentan yang terdaftar dalam data terpadu program penanganan fakir miskin dan orang tidak mampu yang memiliki komponen kesehatan, pendidikan dan kesejahteraan sosial dengan kriteria sebagai berikut: a. Kriteria Komponen Kesehatan meliputi: a) Ibu hamil/ menyusui. b) Anak berusia 0 (nol) sampai dengan 6 (enam) tahun. b. Komponen Pendidikan meliputi: a) Anak Sekolah Dasar/Madrasah Ibtidaiyah atau sederajat. b)
Anak Sekolah Menengah Pertama/Madrasah Tsanawiyah atau sederajat. c) Anak Sekolah Menengah Atas/Madrasah Aliyah atau sederajat. d) Anak usia 6 (enam) sampai dengan 21 (dua puluh satu) tahun yang belum menyelesaikan wajib belajar 12 (dua belas) tahun. c. Komponen Kesejahteraan Sosial. a) Lanjut usia mulai dari 60 (enam puluh) tahun. b) Penyandang disabilitas.

Berdasarkan hasil penelitian dapat kita ketahui bahwasanya masih ada masyarakat yang seharusnya mendapatkan bantuan PKH namun tidak mendapatkan bantuan PKH seperti anak ibu Nu, penyandang disabilitas, ini semua di sebabkan karena kurangnya pengetahuan tentang PKH oleh masyarakat sendiri, padahal untuk mendapatkan atau memasukkan anak ibu $\mathrm{Nu}$ tersebut menjadi penerima PKH itu bisa melalui pendamping atau bisa langsung ke kecamatan atau juga langsung ke Dinas Sosial dan nanti namanya akan langsung di input ke BDT, karena untuk bisa menjadi Program Keluarga Harapan harus terdaftar di Badan Data Terpadu penanganan fakir miskin (BDT).

2) Memastikan Bantuan Tepat Jumlah

Besaran bantuan yang ada dalam buku pedoman pelaksanaan PKH sesuai dengan ketetapan dan dicairkan dalam empat tahap untuk menetapkan besaran bantuan PKH adalah kewenangan Pemerintah Pusat, dan sudah sesuai dengan yang diterima oleh PKH.

Berdasarkan hasil penelitian bahwa untuk ketentuan besaran bantuan tunai PKH sudah diatur oleh pemerintah pusat semua merupakan kewenangan dari pusat, untuk para Koordinator tidak tahu akan hal tersebut, para Koordinator hanya memastikan bahwasanya bantuan sudah cair dan memastikan bantuan sudah masuk ke rekening penerima bantuan PKH. Sedangkan dalam ketepatan jumlah untuk penerimaan bantuan PKH berdasarkan pedoman umum pelaksanaan PKH 2019 sudah sesuai dengan yang diterima oleh PKH.

3) Memastikan Bantuan Tepat Waktu

Dalam penyaluran bantuan tunai program keluarga harapan ada empat tahap dalam satu tahun dana cair ke ATM masing-masing peserta PKH ketika dana sudah cair peserta bisa langsung mengambil bantuan tersebut ke ATM/agen BANK, Pendamping secara aktif memantau pencairan bantuan sosial oleh PKH dan melaporkan ke Koordinator Kabupaten/Kota jumlah KPM yang telah menerima bansos PKH di Tabungan. Untuk masalah pencairan ketika sudah ada informasi dari pihak pusat ke Kabupaten maka uang akan segera cair dan para pendamping akan memantau para PKH dalam proses pencairan.

Berdasarkan dari hasil penelitian untuk pengawasan pelaksanaan PKH masih kurang maksimal seperti bantuan tidak tepat sasaran dan masih ada saja keluarga yang seharusnya tidak mendapatkan namun masih mendapatkan bantuan PKH dan keluarga yang seharusnya mendapatkan bantuan namun tidak mendapatkan bantuan PKH. Kemudian ada PKH yang di keluarkan dari 
kepesertaan PKH karena dianggap sudah mampu tapi ternyata keluarga tersebut sedang mengalami kesusahan, untuk itu pendamping PKH sebagai pengawas tingkat Kecamatan yang selalu turun ke Desa untuk melakukan pendampingan dengan Peserta PKH harus benar-benar lebih teliti lagi untuk memantau keadaan Peserta PKH dan untuk masalah dalam ketepatan waktu penerimaan bantuan memang terjadi permasalahan seperti dana belum masuk kerekening PKH dikarenakan jaringan dan juga saldo PKH nihil, dan seharusnya pendamping PKH harus turut mendampingi para peserta $\mathrm{PKH}$ dalam proses pencairan uangnya karena jikalau ada masalah pendamping langsung mengetahui dan bisa di proses dengan cepat.

e. Evaluasi Program Keluarga Harapan (PKH)

Evaluasi merupakan kegiatan mengukur keberhasilan atau kegagalan dari pelaksanaan PKH dengan menggunakan indikator yang dapat digunakan untuk mengetahui faktor penyebab keberhasilan atau kegagalan dari seluruh tahapan pelaksanaan program. Kegiatan evaluasi didasarkan atas hasil dan dampak pelaksanaan PKH.

1) Peningkatan kualitas hidup keluarga dari aspek pendidikan, kesehatan dan kesejahteraan.

Rendahnya penghasilan menyebabkan keluarga miskin tidak mampu memenuhi kebutuhan kesehatan dan pendidikan, bahkan untuk tingkat minimal sekalipun, pelayanan selama masa kehamilan sampai melahirkan sangat penting bagi keberlangsungan hidup ibu dan bayi termasuk dalam upaya menurunkan kematian ibu dan bayi pada aspek pendidikan tanpa adanya perhatian khusus dari pemerintah anak putus sekolah rentan menjadi korban eksploitasi, termasuk perdagangan anak. Putus sekolah juga berdampak pada banyaknya pengangguran di masa mendatang, selanjutnya pada aspek kesejahteraan, penyandang disabilitas merupakan bagian dari masyarakat Indonesia yang mempunyai hak dan kewajiban yang sama dengan warga negara lainnya. Penyandang disabilitas berhak memperoleh pelayanan yang berhubungan dengan kedisabilitasannya dari pihak lain terutama pengasuhan dan perawatan berbagai upaya sudah dilakukan pemerintah untuk menangani permasalahan penyandang disabilitas yaitu rahabilitasi sosial, jaminan dan perlindungan sosial. Pada hakikatnya penurunan tingkat kemiskinan masyarakat desa memberi gambaran bahwa masyarakat desa juga telah sama-sama merasakan nikmat pembagunan karena mereka telah meningkatkan usaha dari segi pendidikan, keterampilan dan sebagainya sehingga membuka peluang ekonomi.

Berdasarkan hasil penelitian bahwa peningkatan kualitas hidup keluarga dari aspek pendidikan kesehatan dan kesjahteraan sudah tercapai dengan baik sesuai dengan tujuan yang di harapkan dari Program Keluarga Harapan $(\mathrm{PKH})$. kerena adanya program PKH dari pemerintah sehingga jumlah kunjungan dan bumil dan ibu nifas ke failitas kesehatan (posyandu) meningkat.
2) Mengurangi Beban Pengeluaran

Program keluarga harapan (PKH) dapat mengurangi beban pengeluaran keluarga miskin dalam jangka panjang sebab peningkatan kualitas kesehatan, pendidikan dan terpeliharanya tarap penghidupan masyarakat akan memberikan kesempatan kepada masyarakat untuk mampu meningkatkan kualitas dirinya.

Berdasarkan hasil penelitian bahwa dengan adanya bantuan yang telah diberikan oleh pemerintah ini yaitu program keluarg harapan sangat membantu para keluarga miskin terutama dalam bidang pendidikan, mereka bisa menyekolahkan anaknya minimal tingkat sekolah menengah atas (SMA), dengan biaya bantuan dari pemerintah, ketika bantuan yang di berikan seharusnya uang digunakan untuk sekolah anak bisa dialihkan ke yang lain, seperti untuk memenuhi bahan pokok dan lain sebagainya.

3) Kemandirian Program Keluarga Harapan (PKH)

Program perlindungan sosial dari pemerintah, $\mathrm{PKH}$ disebut memiliki muatan pemberdayaan meskipun merupakan cash transfer, namun program tersebut untuk memberikan efek jangka panjang agar masyarakat miskin dapat bangkit dari kondisi kemiskinan. PKH selama ini ditujukan agar masyarakat memiliki kualitas hidup secara lebih meningkat.

Berdasarkan hasil penelitian bahwa untuk hasil dari program keluarga harapan $(\mathrm{PKH})$ sudah sesuai dengan apa yang diharapkan seperti dalam bidang pendidikan dan kesehatan, keluarga yang miskin yang mendapatkan bantuan tersebut bisa menyekolahkan anaknya sampai jenjang minimal SMA sederajat dengan begitu akan memudahkan anak nantinya untuk mendapatkan pekerjaan dan akan bisa membantu orang tua nya untuk memutus rantai kemiskinan, di bidang Kesehatan banyak anak yang sudah mendapatkan gizi baik dan menimbulkan kesadaran bagi keluarga bahwa kesehatan sangat penting.

Faktor yang menghambat upaya peningkatan kesejahteraan masyarakat di Kecamatan Bone-Bone Kabupaten Luwu Utara

a. Komunikasi

Setiap kebijakan yang akan di implementasikan dapat disalurkan kepada orang-orang yang tepat melalui komunikasi yang harus dinyatakan dengan jelas, tepat, dan konsisten.

1) Transmisi

Komunikasi menunjukan proses terjadinya interaksi penyampaian pesan melalui mediator, faktor komunikasi terhadap implementasi adalah pada kejelasan dan isi pesan untuk dapat dipenuhi secara menyeluruh oleh penerimah pesan atau program. Dalam komunikasi yang menjadi penghambat dalam pelaksanaan program keluarga harapan di Kecamatan Bone-Bone adalah transmisi.

Berdasarkan hasil penelitian bahwa proses transmisi berjalan dengan baik, karena sosialisasi yang dilakukan oleh pihak kecamatan yang penangung jawab PKH seksi 
kesejahteraan dan kebersihan Kecamatan Bone-Bone, koordinator kecamatan dan pendamping desa, akan tetapi masyarakat tidak merespon atau menanggapi dengan baik mengenai program PKH sehingga sebagian masyarakat tidak melengkapi berkasnya. Maka solusi yang akan dilakukan untuk perbaikan kedepannya adalah dengan meningkatan jumlah pelaksanaan sosialisasi ditingkat kecamtan atau kelurahan/desa dan melibatkan semua kelompok masyarakat yang ada serta meningkatkan jumlah anggaran pelaksanaan kegiatan $\mathrm{PKH}$.

2) Kejelasan

Kejelasan merupakan salah satu faktor agar implementasi tersebut dapat diterima dengan baik, bila pesan yang disampaikan sangat jelas maka tidak membuat salah interprestasi suatu pesan.

Berkaitan dengan pelaksanaan kegiatan PKH, tenaga pendamping dalam menyampaikan pesan kepada masyarakat terkait dengan kewajiban dan hak bagi peserta $\mathrm{PKH}$, sudah diterima dengan jelas oleh masyarkat.

Hal tersebut terbukti bahwa dari salah seorang penerima PKH sudah paham sekali kn kemana jika ada keluarganya yang mengalami sakit, walaupun pada awalnya masih menghadapi berbagai permasalahan namun setelah dijelaskan dan didampingi maka peserta penerima PKH paham akan hak dan kewajibannya.

Dengan adanya tenaga pendamping yang langsung berhadapan dengan masyaraka maka, pemerintah dari kebijakan yang akan disampaikanebih cepat dan efektif.

Edward III (sebagaimana dikutip dalam Agustino, 2014) mengungkapkan bahwa kejelasan komunikasi yang diterima oleh para pelaksana kebijakan (street level bureuacrats) haruslah jelas dan tidak membingungkan (tidak ambigu/mendua). Kejelasan pesan kebijakan tidak selalu menghalangi implementasi, pada tatanan tertentu, para pelaksana membutuhkan fleksibilitas dalam melaksanakan kebijakan.

Lebih lanjut Edward III (sebagaimana dikutip dalam Winarno, 2014) menjelaskan bahwa dalam rangka mengurangi kadar ketidak jelasan komunikasi kebijakan, maka jauh lebih baik jika dikembangkan saluran-saluran komunikasi yang efektif. Semakin baik dikembangkan saluran-saluran komunikasi untuk meneruskan perintahperintah implementasi, maka semakin tinggi probabilitas perintah-perintah ini diteruskan dengan benar".

3) Konsistensi

Salah satu saryarat agar pelaksanaan impelementasi dapat berlangsung efektif adalah perintah-perintah pelaksanaan harus konsisten dan jelas. Pelaksanaan perintah yang berubah-ubah akan membimbingkan para pelaksanaan kebijakan, disi lain perintah yang tidak konsisten akan mendorong para pelaksana mengambil tindakan yang sangat longgar dalam menafsirkan dan mengimplementasikan kebijakan.

Berdasarkan hasil penelitian menunjukan bahwa pelaksanaan kegiatan PKH yang sudah berjalan dan arahan berupa hak dan kewajiban yang disampaikan kepada penerima manfaat tetap berpedoman pada pedoman umum PKH. Jika terjadi perubahan pada pedoman, maka koordinator PKH kecematanakan menyampaikan kepada tenaga pendamping dan tenaga pendamping juga akan langsung menyampaikan kepada peserta penerima PKH.

Edward III (sebagaimana dikutip dalam Agsutino, 2014) menjelaskan bahwa perintah yang diberikan dalam pelaksanaan komunikasi haruslah konsisten dan jelas (untuk diterapkan atau dijalankan). Karena jika perintah yang diberikan sering berubah-ubah, maka dapat menimbulkan kebingungan bagi pelaksana dilapangan.

Dari hasil penelitian dalam hubungan komunikasi dengan implementasi PKH terdapat beberapa faktor pendukung dan penghambat.

Beberapa faktor pendukung tersebut adalah: Informasi yang disampaikan oleh tenaga pendamping kepada masyarakat terkait pelaksana PKH sudah sangat jelas di mengerti. Ketentuan tentang pelaksanaan PKH yang disampaikan oleh tenaga pendamping sudah konsisten dan tidak berubah-ubah.

Sedangkan faktor penghambat dalam komunikasi ini adalah kurangnya pelaksanaan sosialisasi PKH pada tingkat kelurahan dan desa. Pelaksanaan sosialisasi PKH hanya dapat dilakukan 1 kali dalam 1 bulan di kecamatan Bone-Bone, hal ini disebabkan anggaran yang tersedia tidak mencukupi untuk dapat dilaksanakan 4 kali dalam 1 bulan.

b. Sumberdaya

1) Staf

Ketersediaan staf yang memadai serta memiliki keahlian yang baik akan memudahkan pelaksanaan implementasi diapangan. PKH merupakan progran yang membutuhkan staf yang meiliki keahlian dibidang kemasyarakatan karena bersentuhan langsung pada masyarakat dengan tingkat pendidikan dan kesejahteraan yang rendah.

Jumlah staf pendukung pelaksana PKH di Kecamatan Bone-Bone sebanyak 4 orang yang terdiri dari 1 orang tenaga Koordinator PKH Kecamatan sekaligus sebagai tenaga pendamping desa, 3 orang pendamping desa dan jumlah peserta PKH sebanyak 1.219 peserta yang tersebar di 1 kelurahan dan 10 desa. Tantangan tersendiri bagi pendamping untuk dapat hadir dalam meakukan pertemuan-pertemuan di lapangan, sementara jumlah tenaga pendamping desa di kecamatan bone-bone sebanyak 4 orang, satu orang merangkap sebagai koordinator PKH kecematan dan sebagai pendamping desa dengan demikian maka beban kerja dari tenaga PKH akan semakin berat.

Edward III (sebagaimana dikutip dalam Winamo, 2014) menyampaikan bahwa faktor lain adalah kesulitan dalam merekrut dan mempertahankan administratoradminsitrator yang kompoten karena pada umumnya gaji, prestise dan jaminan kerja mereka yang rendah.

2) Informasi

Informasi merupakan sumberdaya yang penting dalam melaksanakan kebijakan implementasi. Bentuk 
informasi yang digunakan dalam kegiatan PKH ini adalah pedoman umum PKH di dalam pedoman tersebut termuat tentang apa yang harus dilaksanakan dan bagaimana melaksanakan kegiatan PKH.

Informasi yang terdapat dlam pedoman umum antara lain yaitu hak dan kewajiban peserta $\mathrm{PKH}$, mekanisme penetapan sasaran, mekanisme verivikasi, penyaluran bantuan, kelembagaan, sosialisasi dan evaluasi dan monitoring. Pelaksanaan kegiatann PKH di kecamatan bone-bone berjalan dengan baik, karena pelaksana dapat memberikan informasi yang benar terkait dengan hak dan kewajiban bagi peserta PKH.

Disaamping itu pula para tenaga pendamping setiap bulan akan melakukan verifikasi langsung terhadap seluruh penerima PKH baik di fasilitas kesehata maupun di fasilitas pendidikan terkait dengan informasi yang mereka peroleh.

Berkaitan dengan informasi tersebut diatas, Edward III (sebagaimana dikutip dalam Winarno, 2014) menyampaikan bahwa dalam implementasi kebijakan, informasi mempunyai dua bentuk, bentuk pertama informasi bagaimana melaksanakan suatu kebijakan. Pelaksana-pelaksana perlu mengetahui apa yang dilakukan dan bagaimana mereka harus melakukannya. Bentuk kedua dari informasi adalah data tentang ketaatan personil-personil lain terhadap peraturan-peraturan pemerintah. Pelaksana-pelaksana harus mengetahui apakah orang-orang lain yang terlibat dalam pelaksanaan kebijkan mentaati undang-undang ataukah tidak

\section{3) Wewenang}

Pelaksana wewenang dari para pelaksana kegiatan PKH akan mengefektifkan kebijakan implementasi yang akan diterapkan. Setiap pelaksana yang terlibat dalam kegiatan PKH memiliki wewenang secara berjenjang, seperti tenaga pendamping melakukan pencatatan dan pelaporan terhadap keadaan komponen dari keluarga peserta PKH. Sementara koordinator PKH kecamatan berwenang dalam melakukan analisis dan rekomendasi terhadap pelaksana PKH di wilayahnya.

Dengan adanya kewenangan memverifikasi terhadap pelaksana PKH oleh tenaga pendamping dan koordinator PKH kecamatan maka, pembayaran yang diterima oleh peserta PKH akan ssuai dengan hak dan tanggung jawab yang diberikan kepada mereka.

Penjelasan ini diperkuat pendapat Edward III dalarn Agustino (2014) bahwa pada umumnya kewenangan hams bersifat formal agar perintah dapat dilaksanakan. Kewenangan merupakan otoritas atau legitimasi bagi para pelaksana dalam melaksanakan kebijakan yang ditetapkan.

\section{4) Fasilitas}

Dari sumberdaya yang menghambat pelaksanaan kegiatan PKH di kecamatan bone-bone adalah fasilitas. Dalam rangka mendukung pelaksanaan kegiatan PKH, pemerintah diwajibkan menyediakan sarana berupa kantor sekretariat beserta fasilitas pendukungnya yang ada di kecamatan.
Hasil penelitian menunjukan bahwa sekretarian UPPKH Kecamtan Bone-Bone berlokasi di Kantor kecamatan Bone-Bone. Dengan terbatasnya fasilitas sarana dan prasana yang ada, maka membuat pelaksanaan kegiatan PKH kecamatan berjalan seadanya.

Dari hasil penelitian dalam hubungan sumberdaya dengan pelaksanaan $\mathrm{PKH}$, terdapat beberapa pendukung dan penghambat. Beberapa faktor pendukung tersebut adalah:

a) tersedianya jumlah staf pendamping yang memiliki kemampuan dan pengalam dalam bidang pemberdayaan masyarakat.

b) Adanya pedoman umum pelaksanaan PKH sebagai pedoman tenaga pendamping dalam melaksanakan kegiatan PKH. c) Adanya wewenng dari tenaga pendamping dalam melakukan verivikasi dan validasi terhadap penerima PKH.

Sedangkan faktor penghambat dalam sumberdaya ini adalah dengan terbatasnya fasilitas sarana dan prasana yang ada, maka membuat pelaksanaan kegiatan PKH kecamatan berjalan seadanya. Tugas dan tanggungjawab pendamping PKH kecamatan secara umum adalah melaksanakan tugas pendamping kepada peserta PKH. Wilayah kerja meliputi seluruh kelurahan/desa dalam suatu wilayah kerja kecamatan. Sehubungan dengan tugas dan tanggungjawab tersebut, maka sekretariat UPPKH kecamatan sangat berpengaruh terhadap keberhasilan atau gagalnya dari kegiatan PKH. Hal ini sejalan dengan yang disampikan oleh Edward III (sebagaimana dikutip dalam Winarno, 2014) menyampaikan bahwa sebab seorang pelaksana mungkin mempunyai staf yang memadai, mungkin memahruru apa yang akan dilakukan dan mungkin mempunyai wewenang untuk melakukan tugasnya, tetapi tanpa kantor/bangunan maka besar kemungkinan implementasi yang direncanakan akan gagal.

c. Stuktur Organisasi

1) Standar Operating Prosedures (SOPs)

Dalam pelaksanaan kegiatan PKH Standar Operating Prosedures (SOPs) yang digunakan sudah ditentukan dari pemerintah pusat, SOPs tersebut dimanfaatkan dalam rangka menetapkan sasaran, verifikasi, pembayaran dan sanksi bagi peserta PKH.

Edward III dalam Winamo (2014:207) menyatakan bahwa dengan menggunakan SOP, para pelaksana dapat memanfaatkan waktu yang tersedia, selain itu SOP juga menyeragamkan tindakan-tindakan dari para pejabat dalam organisasi-organisasi yang kompleks dan tersebar luas, yang pada gilirannya dapat menimbulkan fleksibitas yang besar (orang dapat dipindahkan dengan mudah dari satu tempat ke tempat lain) dan kesamaan yang besar dalam penerapan peraturan-peraturan.

Pelaksanaan verifikasi sasaran yang dilakukan oleh tenaga pendamping, mengacu pada SOP yang sudah ditentukan oleh Kementerian Sosial. Hasil verifikasi dan validasi tersebut digunakan sevagai dasar pembayaran terhadap peserta $\mathrm{PKH}$.

2) Fragmentasi 
PKH merupakan program dari pemerintah pusat agar dapat berjalan dengan baik maka keterlibatan pemerintah daerah sangat diperlukan guna keberhasilan dari program ini. Tanggungjawab dari masing-masing pemangku kepentingan baik dari pusat, provinsi dan daerah harus jelas agar para pelaksana implementasi dapat berbuat sesuai dengan tugas dan fungsi masing-masing atau tidak terjadinya tumpang tindih tugas pokok dan fungsi.

Begitu juga di daerah pembagian tugas dan fungsi sudah harus dibedakan antara Dinas teknis pelaksana dengan koordinator PKH kabupaten, tenaga pendamping dan pihak Kecamatan dan Kelurahan/Desa serta pihak PT. Pos Indonesia dapat mengetahui tugasnya masing-masing.

Edward III dalam Agustino (2014) menyampaikan bahwa fragmentasi adalah upaya penyebaran tanggung jawab kegiatan-kegiatan atau aktivitas-aktivitas pegawai di antara beberapa unit kerja.

Dari hasil penelitian dalam hubungan struktur organisasi yang menjadi pendukung dalam pelaksanaan PKH adalah sebagai berikut: a) Adanya SOPs sebagai bahan dan pedoman dalam melaksanakan kegiatan PKH. b) Adanya tugas dan fungsi yang jelas pada struktur organisasi pelaksana PKH mulai dari tingkat kabupaten, kecamatan, kelurahan dan desa.

\section{KESIMPULAN DAN SARAN}

Hasil pembahasan dapat disimpulkan bahwa upaya pemerintah kecamatan Bone-Bone Kabupaten Luwu Utara dalam meningkatkan kesejahteraan masyarakat sudah cukup berjalan dengan baik akan tetapi masih ada beberapa hal yang perlu diperbaiki dan di tata lebih baik lagi seperti para pendamping PKH tidak melibatkan masyarakat umum dalam sosialisasi PKH sehingga banyak masyarakat yang seharusnya mendapatkan bantuan PKH namun tidak menerima bantuan. Kurangnya pengetahuan calon PKH tentang prosedur PKH mengakibatkan terjadinya masalah seperti ketika para calon PKH telah terdaftar menjadi penerima PKH namun saat validasi ternyata tidak susuai dengan syarat yang telah ditetapkan, seperti harus adanya komponen pendidikan, kesehatan dan kesejahteraan sosial, sehingga terjadilah kecemburuan sosial antara masyarakat tersebut. Terjadinya keterlambatan dalam pencairan uang disebabkan karena saldo peserta PKH nihiil dan juga di karenakan jaringan. Tidak adanya pendampingan dari pendamping PKH dalam proses pengambilan uang oleh PKH sehingga untuk pengambilan uang bebas siapa saja dari keluarga peserta PKH.

Agar pelaksanaan sosialisasi dapat berjalan sampai tingkat kecamatan dan kelurahan/desa, maka Pemerintah Daerah perlu menambah anggaran pada kegiatan PKH. Menyediaan kantor sekretariat UPPKH pada tingkat kecamatan agar pelaksanaan kegiatan PKH dapat berjalan secara maksimal. Perlunya rekrutmen staf atau pegawai $\mathrm{PKH}$, melibatkan pemerintah daerah, agar penempatan wilayah kerja sesuai dengan tempat tinggalnya. Perlunya ditingkatkan sheering dari pemerintah daerah, terutama diperuntukkan bagi operasional sekretariat UPPKH Kecamatan dan insentif bagi tenaga pendamping di lapangan.

\section{DAFTAR PUSTAKA}

Agustino L (2014). Dasar-dasar Kebijakan Publik. Bandung. Alfabeta.

Baroroh, A (2008). Trik-trik Analisis Statistik dengan SPSS 15. Jakarta : Elex Media Komputino

Bungin, Burhan. (2003). Analisis Data Penelitian Kualitatif (Pemahaman Filosofis dan Metodologis ke arah Penguasaan Model Aplikasi). Jakarta: PT. Rajagrafindo Persada.

Conyers. Diana. (1994). Perencanaan Sosial di Dunia Ketiga. Terjemahan Susetiawan. Yogyakarta: Gadjah Mada University Press.

Direktorat Jaminan Sosial. (2012). Pedoman Oprasional PKH Bagi Pemberi Pelayanan Kesehatan. Jakarta: Direktorat Jenderal Perlindungan dan Jaminan Sosial. Kementerian Sosial RI.

Direktorat Jaminan Sosial. (2013). Pedoman Umum Program Keluarga Harapan (PKH). Jakarta: Direktorat Jenderal Perlindungan dan Jaminan Sosial. Kementerian Sosial RI.

Direktorat Jaminan Sosial. (2013). Pedoman Operasional PKH Bagi Pemberi Pelayanan Pendidikan. Jakarta: Direktorat Jenderal Perlindungan dan Jaminan Sosial. Kementerian Sosial RI.

Direktorat Jaminan Sosial. (2013). Pedoman Oprasional Penyaluran Dana Bantuan PKH. Jakarta: Direktorat Jenderal Perlindungan dan Jaminan Sosial. Kementerian Sosial RI.

Dunn, William N, (2003). Pengantar Analisis Kebijakan Publik. Edisi Kedua. Yogyakarta. Gadjah Mada University Press.

Effendi, Tadjuddin Noer, (1993). Sumberdaya Manusia, Peluang Kerja dan Kemiskinan. Yogyakarta: PT. Tiara Wacana.

Indiahono, Dwiyanto. (2009). Kebijakan Publik Berbasis Dynamic Policy Analisys. Y ogyakarta: Penerbit Gava Media.

Kartasasmita, Ginanjar, (1997). Administrasi Pembangunan: Perkembangan Pemikiran dan Praktiknya di Indonesia, Jakarta: LP3ES.

Keputusan Menteri Sosial Republik Indonesia No. 02A/HUK/2008. tentang Tim Pelaksana Program Keluarga Harapan.

Kunarjo, (2002). Perencanaan dan Pengendalian Program Pembangunan. Jakarta: Penerbit Universitas Indonesia.

Kuncoro, Mudrajat, (2004). Otonomi Daerah-Reformasi, Perencanaan Startegis dan Peluang. Jakarta: Penerbit Erlangga.

Lewis, John P dan Valeriana Kallab (Eds).1987. Mengakji Ulang Strategi-strategi Pembangunan. Terjemahan : Pandam Guritno, Jakarta : Penerbit Universitas Indonesia. 
Merdimin, Johanes (1996). Dimensi Kritis Proses Pembangunan di Indonesia. Yogyakarta : Penerbit Kanisius.

Mulyadi, Deddy. (2015). Studi Kebijakan Publik dan Pelayanan Publik. Bandung: Penerbit Alfabeta.

Moleong, Lexy J. (2007) Metodologi Penelitian Kualitatif. Bandung: Remaja Rosdakarya Off set.

Nasution, S., Prof. Dr. MA. (2005). Metode Research (Penelitian Ilmiah Edisi Keenam). Bandung: Bumi Aksara

Nazir, Moh. (1999) Metode Penelitian, Jakarta : Ghalia Jakarta.

Penyusunan, Pengendalian Dan Evaluasi Pelaksanaan Rencana Pembangunan Daerah

Peraturan Presiden Nomor 14 Tahun 2010. tentang Percepatan Penanggulangan Kemiskinan.

Peraturan Menteri Dalam Negri No. 54 Tahun 2010 tentang Pelaksanaan

Peraturan Pemerintah No. 08 Tahun 20108 tentang Tahapan, Tatacara

Prasetya, Irawan. (2012). Metodologi Administrasi Penelitian. Jakarta: Penerbit. Universitas Terbuka

Purwanto, EA dan Sulsityastuti, DR. (2012). Implementasi Kebijakan Publik. Yogyakarata: Penerbit Gava Media

Sugiyono, (2007). Memahami Penelitian Kuantitatif. Bandung: CV. Alfabeta.

Undang-Undang Dasar 1945

Undang-Undang No.40 Tahun 2004 tentang Sistem Jaminan Sosial Nasional

Undang-Undang No.13 Tahun 2011 tentang Penangana Fakir Miskin.

Winarno B, (2014). Kebijakan Publik: Teori, Proses dan Studi Kasus. Yogyakarta. Caps Publishing 